\title{
Study on the Impact of Activators in the Presence of an Inhibitor on the Dynamics of Carbon Dioxide Absorption by Chlorophyll-Synthesizing Microalgae
}

\author{
Vasil V. Dyachok ${ }^{1 *}$, Solomiia T. Mandryk' ${ }^{1}$, Sergii I. Huhlych', Maria M. Slyvka ${ }^{1}$ \\ 1 Lviv Polytechnic National University, 12 Bandera street, Lviv, Ukraine, 7901 \\ * Corresponding author's e-mail: dyachokvasil@gmail.com
}

\begin{abstract}
The work demonstrates the suppression of the inhibiting effect of the carbon dioxide absorption process by chlorophyll-synthesizing Chlorella microalgae due to sulfur oxide $\mathrm{SO}_{2}$, activators of phosphorus oxide $\mathrm{P}_{2} \mathrm{O}_{5}$ and nitrogen oxides $\mathrm{N}_{x} \mathrm{O}_{y}$ The research presents the experimental dependences of the dynamics of $\mathrm{CO}_{2}$ absorption by microalgae under the critical concentration of inhibitor $\mathrm{SO}_{2}$ in the presence of the $\mathrm{P}_{2} \mathrm{O}_{5}$ and $\mathrm{N}_{x} \mathrm{O}_{y}$ activators. The authors devised the mathematic models of growth of the Chlorella microalgae population depending on the concentration of the phosphorus oxide and nitrogen oxides activators under a permanent concentration of the sulfur oxide inhibitor. The research determined an optimal total concentration of $\mathrm{P}_{2} \mathrm{O}_{5}$ activator in the presence of the $\mathrm{SO}_{2}$ inhibitor, as well as an optimal total concentration of the $\mathrm{NO}_{2}$ activator in the presence of the $\mathrm{SO}_{2}$ inhibitor.
\end{abstract}

Keywords: carbon, phosphorus, nitrogen, sulfur oxides, microalgae, inhibitors, activators

\section{INTRODUCTION}

The problem of global climate change is caused by a continuous increase in the volume of greenhouse gases in the atmosphere. Global warming causes a set of problems, including the sea level increase (increasing the risk of floods on one hand, and draughts on the other hand), increased number and intensity of hurricanes, as well as extinction of some species of plants and animals. The climatic changes also make the process of growing of some food products more complicated, particularly in the countries of Africa, and the reserves of fresh water are becoming reduced [1]. The ecological community alarms because the issue is a top problem of the present day and needs an urgent solution at the state level.

The International Climate Treaty, i.e. Paris Agreement, was adopted on December 12, 2015. The Paris Agreement was signed by 175 countries, including Ukraine, at the official ceremony on April 22, 2016. The Supreme Council of Ukraine ratified the Paris Agreement on July 14, 2016 [2].
The goal of the Paris Agreement is to intensify the global fight against the threat of climate changes for the inhibition of the temperature rise on the planet to the level significantly lower than by 2 Celsius degrees, as compared to the pre-industrial levels. The Paris Climate Agreement suggests that the commitments to reduce the harmful emissions in the atmosphere are taken by all states, regardless of the level of their economic development [3].

Ukraine should take all opportunities and mechanisms, expected for the implementation of the Paris Climate Agreement. Thus, the state will considerably reduce the emissions of greenhouse gases, cut down the consumption of traditional energy resources, increase the share of renewable sources, modernize the economy, and improve the living standards of citizens.

Recently, the 50 ${ }^{\text {th }}$ World Economic Forum was held in Davos. The principal topics of the Forum suggested establishment of capitalism for all interested parties and ecological situation in the world. Considering horrible natural disasters 
of the last year, the issue of rapid climate changes and their consequences was much concerned. The climatic changes occur fast, and in the war, declared by people to the nature, the nature is hurt very severely [4].

A change of climate is so dangerous that the response to it does not require just a complex of measures, but also changes of the consumption model. The humanity is under the unprecedented threat due to contribution to the change of climate, pollution of nature, exhaustion of water resources, and extinction of numerous kinds of living organisms. Hence, it is necessary to reconcile the economic growth and natural capabilities.

The majority of the greenhouse gases are emitted by burning of fuel, particularly solid, liquid or gaseous. The main greenhouse gas, emitted in the atmosphere, is carbon dioxide $\mathrm{CO}_{2}$. Thus, the reduction of the $\mathrm{CO}_{2}$ emissions is the main task of modern ecological community.

The process of fuel combustion produces byproduct greenhouse gases like phosphorus oxide $\left(\mathrm{P}_{2} \mathrm{O}_{5}\right)$, nitrogen oxides $\left(\mathrm{N}_{\mathrm{x}} \mathrm{O}_{\mathrm{y}}\right)$, sulfur oxide $\left(\mathrm{SO}_{2}\right)$ and others. Under the real conditions, there is no an individual effect of the components, which influence the process of carbon dioxide absorption. Thus, it is important to study the total impact of combustion products, particularly phosphorus oxide $\left(\mathrm{P}_{2} \mathrm{O}_{5}\right)$, nitrogen oxides $\left(\mathrm{N}_{\mathrm{x}} \mathrm{O}_{\mathrm{y}}\right)$ and sulfur oxide $\left(\mathrm{SO}_{2}\right)$, on the speed of carbon dioxide absorption on the example of the chlorophyll-synthesizing Chlorella microalgae.

The biological fixation of $\mathrm{CO}_{2}$ by means of the chlorophyll-synthesizing Chlorella microalgae is considered as a potential tactics not only to reduce the emissions of carbon dioxide, but also to obtain the biomass of the microalgae with a high share of lipids (source of regenerative energy). Inclusion of $\mathrm{CO}_{2}$ in the components of energy reserve in biomass, such as carbohydrates and lipids, which is based on photosynthesis and fixation of $\mathrm{CO}_{2}$, is the most prospective way to capture the carbon dioxide of the gas emissions [5].

An individual impact of sulfur oxide $\left(\mathrm{SO}_{2}\right)$, as an inhibitor, as well as phosphorus oxide $\left(\mathrm{P}_{2} \mathrm{O}_{5}\right)$ and nitrogen oxides $\left(\mathrm{N}_{\mathrm{x}} \mathrm{O}_{\mathrm{y}}\right)$, as activators, on the speed of carbon dioxide $\left(\mathrm{CO}_{2}\right)$ absorption is described in the works $[6,7,8,11]$. These publications contain little information about the simultaneous impact of $\mathrm{SO}_{2}, \mathrm{P}_{2} \mathrm{O}_{5}$ and $\mathrm{N}_{\mathrm{x}} \mathrm{O}_{\mathrm{y}}$ on the efficiency of $\mathrm{CO}_{2}$ absorption. Thus, it is important to study the total impact of the $\mathrm{SO}_{2}$ inhibitor as well as the $\mathrm{P}_{2} \mathrm{O}_{5}$ and $\mathrm{N}_{\mathrm{x}} \mathrm{O}_{\mathrm{y}}$ activators on the dynamics of the carbon dioxide $\mathrm{CO}_{2}$ absorption by the chlorophyll-synthesizing Chlorella microalgae.

The aim of the work was to determine an optimal correlation of concentration of the $\mathrm{SO}_{2}$ inhibitor and $\mathrm{P}_{2} \mathrm{O}_{5}$ activator as well as the $\mathrm{SO}_{2}$ inhibitor and $\mathrm{N}_{\mathrm{x}} \mathrm{O}_{\mathrm{y}}$ activator, which secures the most efficient absorption of carbon dioxide by the chlorophyll-synthesizing microalgae of Chlorella type.

\section{METHODS}

All processes in the nature happen in exclusively fermentative way. Thus, the transformation of pollutants inside a cell of microalgae happens under the effect of ferments. Ferments are the catalysts, the activity of which can be regulated. Most ferments can be bound by small molecules, which are called modifying factors (effectors) and can change the fermentative activity. They include inhibitors, i.e. compounds, which stagnate the activity of the ferment, and activators, i.e. compounds, which accelerate the fermentative activity. Thus, the results of the inhibitors' effect is called inhibiting, whereas the one of activators is called activation [9]. In the current case, the activators of the carbon dioxide $\left(\mathrm{CO}_{2}\right)$ absorption process by chlorophyll-synthesizing microalgae are represented by phosphorus oxide $\left(\mathrm{P}_{2} \mathrm{O}_{5}\right)$ and nitrogen oxides $\left(\mathrm{N}_{\mathrm{x}} \mathrm{O}_{\mathrm{y}}\right)$, whereas sulfur oxide $\left(\mathrm{SO}_{2}\right)$ is the inhibitor -. In nature, inhibiting and activation of ferments and fermentative systems provide an important way to regulate metabolism and accommodation to the environmental conditions.

The simplest scheme of impact of some agent $\boldsymbol{R}$ on the fermentative transformation of the substrate $\boldsymbol{S}$ into the product $\boldsymbol{P}$ suggests the inverse interaction of that substance with the ferment or the ferment-substrate complex:

$$
\begin{gathered}
E+S_{K_{S}} E S \stackrel{k k_{2}}{\rightarrow} E+P \\
++ \\
\mathrm{R} \mathrm{R} \\
\uparrow \downarrow \mathrm{K}_{\mathrm{R}} \uparrow \downarrow a K_{R} \\
E R+S \underset{a H_{S}}{\longrightarrow} R E S \stackrel{\beta k_{2}}{\longrightarrow} E R+P
\end{gathered}
$$

$\mathrm{K}_{\mathrm{S}}$ and $\mathrm{K}_{\mathrm{R}}$ stand for the constants of unstable complexes of a ferment with a substrate and with a substance $\boldsymbol{R}$. The general thermodynamic suggestions confirm that for a closed system of balances (1) of the constant of unstability of a triple 
complex RES during its breaking by two possible directions, should differ from the constant of unstability of the corresponding double ones by the same number of times that is considered by the coefficient $\boldsymbol{a}$. If breaking of the ferment-substrate complex with formation of a product happens with the constant of speed $\mathrm{k}_{2}$, the triple complex can be transformed with production of the same product with another constant of speed $\beta \mathrm{k}_{2}$. The value $\beta$ determines the influence of the added substance: under $\beta>1$, it accelerates the reaction and is called an activator (A); under $\beta<1$, the reaction is slowed and the supplement is called an inhibitor (I), whereas in the case when $\beta=0$, it is called total inhibiting. The cases of simultaneous effects of inhibitors and activators in one system are ambiguously described in literature. However, such cases are common in practice.

\section{RESULTS AND DISCUSSION}

In order to study the influence of activation and inhibiting on the process of carbon dioxide absorption, the authors used the Chlorella vulgaris microalgae. They were cultivated over 11 days in six photobioreactors of $1 \mathrm{dm}^{3}$ volume. The cells of microalgae obtain the nutrient materials, i.e. carbon dioxide and elements of mineral nutrition, directly from the liquid environment, absorbing them by their surface. While conducting the research, the temperature was supported about $\mathrm{t}=30^{\circ} \mathrm{C}$ to reach the maximum favorable conditions of cultivation. The $\mathrm{P}_{2} \mathrm{O}_{5}, \mathrm{~N}_{\mathrm{x}} \mathrm{O}_{\mathrm{y}}$ and $\mathrm{SO}_{2}$ oxides are absorbed by microalgae in the form of $\mathrm{H}_{2} \mathrm{PO}_{4}^{-} ; \mathrm{HSO}_{3}^{-}$anions and thus, their influence on the growth of the chlorophyll-synthesizing microalgae was studied under different values of concentration of activators and permanent concentration of an inhibitor. The value of critical concentration of the inhibitor was determined experimentally and presented in the paper [6].

In order to study the impact of the activator of phosphorus oxide $\left(\mathrm{P}_{2} \mathrm{O}_{5}\right)$ in the presence of the sulfur oxide $\left(\mathrm{SO}_{2}\right)$ inhibitor, the researchers added only the $\mathrm{HSO}_{3}^{-}$anion at the concentration of $1000 \mathrm{mg} / \mathrm{m}^{3}$ in the first photobioreactor in order to confirm that sulfur oxide was the growth inhibitor of the chlorophyll-synthesizing Chlorella microalgae. In the second photobioreactor and all others, the $\mathrm{HSO}_{3}^{-}$anion was added at the concentration of $1000 \mathrm{mg} / \mathrm{m}^{3}$, whereas the $\mathrm{H}_{2} \mathrm{PO}_{4}^{-}$anion at the concentration of $0.0035 \mathrm{mg} / \mathrm{m}^{3}$; in the third $-0.005 \mathrm{mg} / \mathrm{m}^{3}$; in the fourth $-0.01 \mathrm{mg} / \mathrm{m}^{3}$; and in the fifth $-0.02 \mathrm{mg} / \mathrm{m}^{3}$. The same amount of the $\mathrm{HSO}_{3}^{-}$anion and different amounts of the $\mathrm{H}_{2} \mathrm{PO}_{4}^{-}$ anion were added to all samples, and the control solution, which did not contain any added anion in the process of the research.

In order to examine the influence of the nitrogen oxide $\left(\mathrm{N}_{\mathrm{x}} \mathrm{O}_{\mathrm{y}}\right)$ activator in the presence of the sulfur oxide $\left(\mathrm{SO}_{2}\right)$ inhibitor, the researchers added only the $\mathrm{HSO}_{3}^{-}$anion at the concentration of $1000 \mathrm{mg} / \mathrm{m}^{3}$ in the first photobioreactor. In the second photobioreactor and all others, the $\mathrm{HSO}_{3}^{-}$anion was added at the concentration of $1000 \mathrm{mg} / \mathrm{m}^{3}$ and the $\mathrm{NO}_{3}^{-}$anion at the concentration of $8.6 \mathrm{mg} / \mathrm{m}^{3}$; in the third $-17.2 \mathrm{mg} / \mathrm{m}^{3}$; in the fourth $-25.8 \mathrm{mg} / \mathrm{m}^{3}$; and in the fifth $34.4 \mathrm{mg} / \mathrm{m}^{3}$. Thus, the same amount of the $\mathrm{HSO}_{3}^{-}$ anion and different amounts of the $\mathrm{NO}_{3}^{-}$anion were added to all samples.

Under such conditions, the biomass growth of the chlorophyll-synthesizing microalgae was determined by means of the photocolorimetric method with application of blue light filter according to the Beer-Lambert-Bouguer law. As the optical density is proportional to concentration, the obtained experimental data of the microalgae biomass accumulation, depending on the time, correspond to the values of optical densities within the total studied concentration of $\mathrm{H}_{2} \mathrm{PO}_{4}^{-}$ and $\mathrm{HSO}_{3}^{-} ; \mathrm{NO}_{3}^{-}$and $\mathrm{HSO}_{3}^{-}$.

While processing the experimental data, the authors obtained the graphical dependences, illustrating the change of microalgae concentration in time under a permanent concentration of the inhibitor and different values of activators concentration in the solution under its single input (Fig. 1, 2).

The obtained data confirm that the $\mathrm{HSO}_{3}^{-}$ anion is the inhibitor of the microalgae growth process that is demonstrated by the diagram. The first sample, as compared to the control and other samples, demonstrates a definite fall. While analyzing the data (Fig. 1), it is worth noting that an increase in the concentration of microalgae cells significantly depends on the concentration of the anion $\left(\mathrm{H}_{2} \mathrm{PO}_{4}^{-}\right)$, which acts an activator of the process of carbon dioxide absorption. The samples 2-4 demonstrate that the anion $\left(\mathrm{H}_{2} \mathrm{PO}_{4}^{-}\right)$ activates the effect of the inhibitor $\mathrm{HSO}_{3}^{-}$and accompanies the process of microalgae growth. In the variant of the fifth sample, one can see that the added concentration of the $\mathrm{H}_{2} \mathrm{PO}_{4}^{-}$anion has a destructing effect on the growth and thus, microalgae die. 


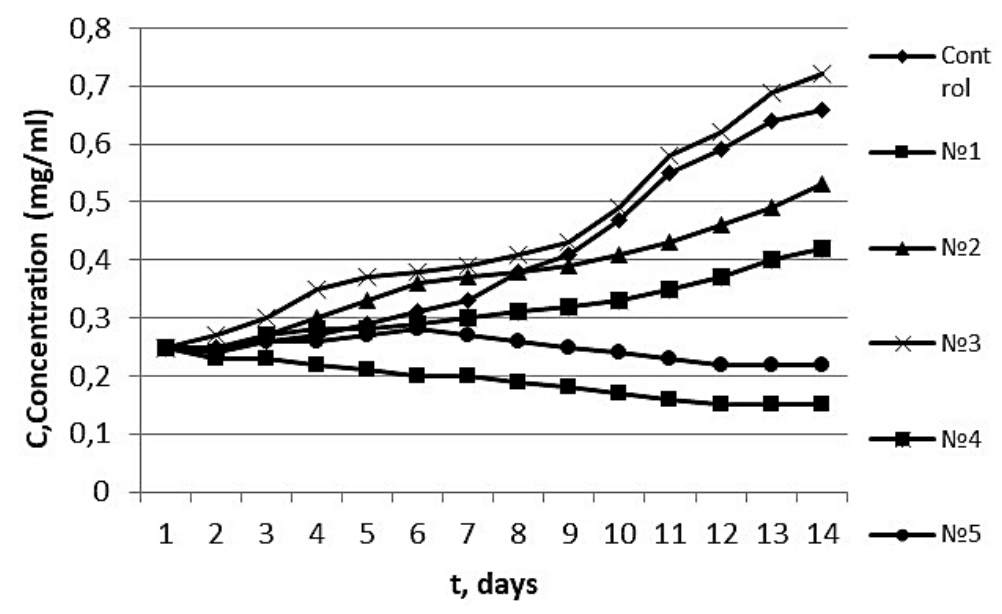

Fig. 1. Dependence of the change of concentration of microalgae cells in time under the corresponding concentrations of the $\mathrm{HSO}_{3}^{-}$anion and the $\mathrm{H}_{2} \mathrm{PO}_{4}^{-}$anion

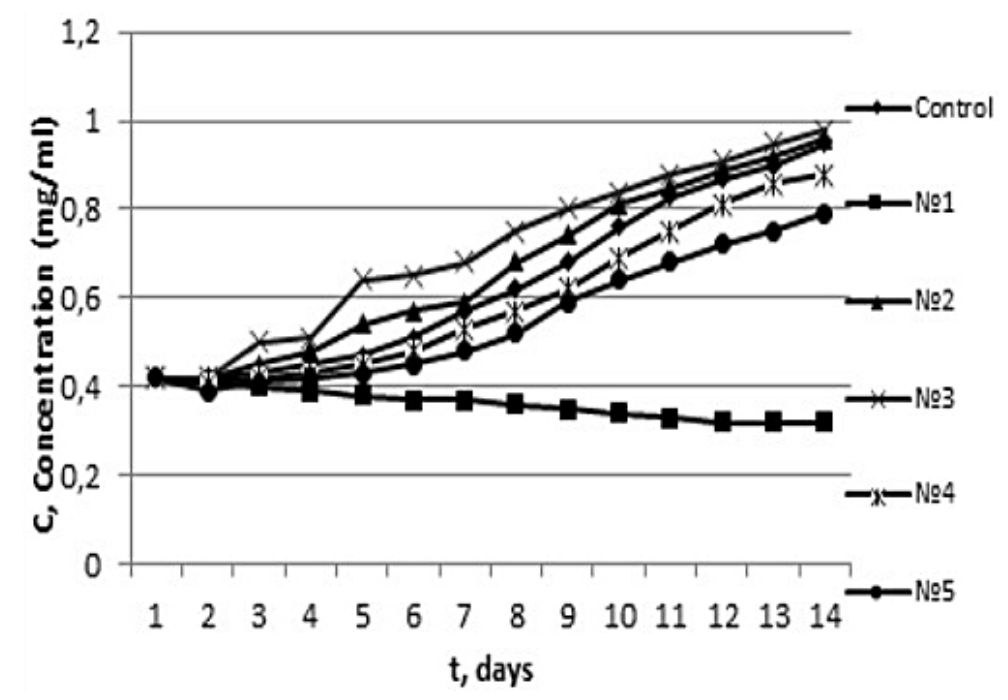

Fig. 2. Dependence of the change of concentration of microalgae cells in time under the corresponding values of the content of $\mathrm{HSO}_{3}^{-}$and $\mathrm{NO}_{3}^{-}$

The further analysis of the data (Fig. 2) secures the similar conclusion that an increase of the microalgae cells concentration significantly depends on the concentration of nitrogen oxide $\left(\mathrm{NO}_{3}^{-}\right)$, and that fact suggests that the anion $\left(\mathrm{NO}_{3}^{-}\right)$acts as an activator of the process of carbon dioxide absorption. The samples 2-5 demonstrate that the anion $\left(\mathrm{NO}_{3}^{-}\right)$activates the effect of the inhibitor $\left(\mathrm{HSO}_{3}^{-}\right)$and it is accompanied by the growth of microalgae.

The crucial parameter, which characterizes the growth of microalgae $\delta_{\mu}$, is the specific speed of growth:

$$
\delta_{k}=\delta C / C \cdot \delta t
$$

where: $C$-is concentration of microalgae,

$\delta_{\mu}$ - the specific speed of growth or the coefficient of specific growth $\left(\mathrm{c}^{-1}\right)$.
The growth factor can be calculated by the equation:

$$
\delta C / \delta t=\mu \cdot C
$$

According to the equation, the growth factor $\mu$ features a relative growth of the microalgae density per time unit. If $\delta \mu$ stays unchanged during a definite period, such growth is called exponential, and the corresponding period of time is called an exponential phase of growth.

Having integrated the equation (3), the constant of the integrating is found in case of availability of the primary density of the cells of microalgae $C_{0}$ at the starting moment of time $t=0$.

$$
C=C_{0} \cdot \exp (\mu t)
$$

In turn, the logarithmic dependence of the concentration of microalgae cells on time in the 
period of exponential growth is a linear dependence, which provides the opportunity to determine the growth factor $\mu$ as a tangent of the slope angle of the experimental right line. Thus, inserting the experimental data in the equation (4), the authors have obtained the dependences $\operatorname{Ln}\left(C / C_{o}\right)=f(t)$, which are depicted at the Figure 3; 4 in the variant when phosphorus oxide acts as an activator.

Using the obtained results, the authors determined the growth factor $\mu$ as a tangent of the slope angle of experimental right lines at the figures (Fig. 3; Fig. 4). In the control container, an increase in the growth of the microalgae biomass can be observed. Thus, the value of the coefficient of growth is positive, i.e. $\mu=0.1606 \mathrm{c}^{-1}$ (Fig. 3). The values of the growth factor $\mu$ under the corresponding concentrations of the $\mathrm{H}_{2} \mathrm{PO}_{4}^{-}$ anions and permanent concentration of $\mathrm{HSO}_{3}^{-}$, are presented in Table 1. The samples 2-4 demonstrate an increase in the growth of the microalgae biomass and thus, the value of the growth factor is positive. In the case of the first sample, when only the inhibitor $\mathrm{HSO}_{3}^{-}$is added, and in the variant of the fifth sample, when a fatal concentration of the $\mathrm{H}_{2} \mathrm{PO}_{4}^{-}$anions is added, a reduction in the growth of microalgae biomass can be observed and thus, the value of the growth factor $\mu$ is negative. In the case of nitrogen oxides, the authors obtained the dependences, depicted in Figures 5 and 6.

According to the obtained graphical dependences (Fig. 5; Fig. 6), the authors determined the growth factor $\mu$ as a tangent of the slope angle of experimental rights lines. In the control container,

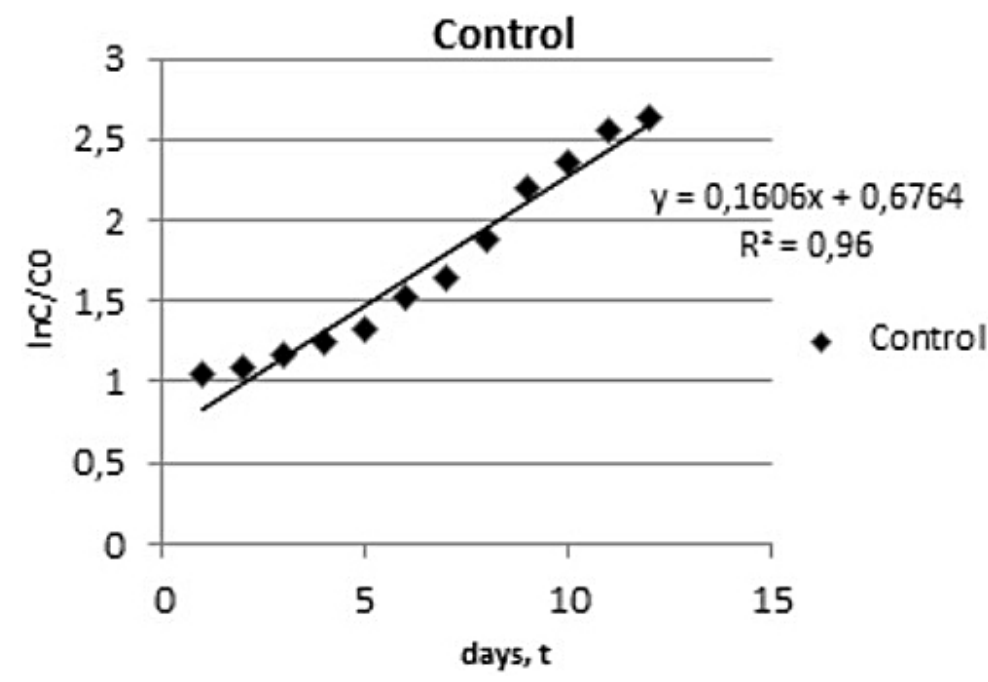

Fig. 3. Dependence of a change of the logarithm of cells concentration in microalgae suspension on time (control)

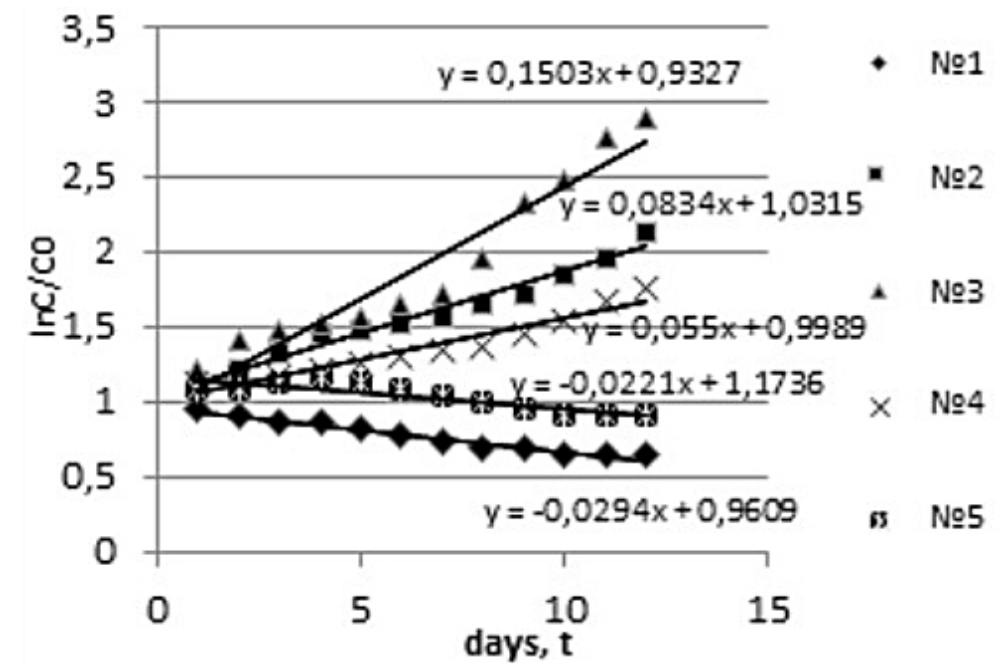

Fig. 4. Dependence of a change of the logarithm of cells concentration in microalgae suspension on time (under the corresponding concentrations of the $\mathrm{H}_{2} \mathrm{PO}_{4}^{-}$activator and the per $\mathrm{HSO}_{3}^{-}$permanent inhibitor) 
Table 1. Values of the growth factor $\mu$ under the corresponding concentrations of the $\mathrm{H}_{2} \mathrm{PO}_{4}^{-}$and $\mathrm{HSO}_{3}^{-}$anions

\begin{tabular}{|c|c|c|c|}
\hline Sample & Growth factor $\mu \mathrm{c}^{-1}$ & Concentration $\mathrm{HSO}_{3}^{-} \mathrm{mg} / \mathrm{m}^{3}$ & Concentration $\mathrm{H}_{2} \mathrm{PO}_{4}^{-} \mathrm{mg} / \mathrm{m}^{3}$ \\
\hline Control & 0.1606 & - & - \\
\hline Sample No. 1 & -0.0294 & 1000 & - \\
\hline Sample No. 2 & 0.0834 & 1000 & 0.0035 \\
\hline Sample No. 3 & 0.1503 & 1000 & 0.005 \\
\hline Sample No. 4 & 0.055 & 1000 & 0.01 \\
\hline Sample No. 5 & -0.0221 & 1000 & 0.02 \\
\hline
\end{tabular}

the (natural) process of increased growth of microalgae biomass is common and thus, the value of the growth factor is positive, i.e. $\mu=0.1234 \mathrm{c}^{-1}$ (Fig. 5). The values of the growth factor $\mu$, under the permanent concentration of the $\mathrm{HSO}_{3}^{-}$inhibitor and different concentration of the $\mathrm{NO}_{3}^{-}$activator, are presented in Table 2. In the samples 2-5, the dynamics of growth of microalgae biomass is positive, and the value of the coefficient $\mu$ is positive. In the case of the first sample, under the conditions of the inhibitor presence, when only the $\mathrm{HSO}_{3}^{-}$anion is added, a negative dynamics of

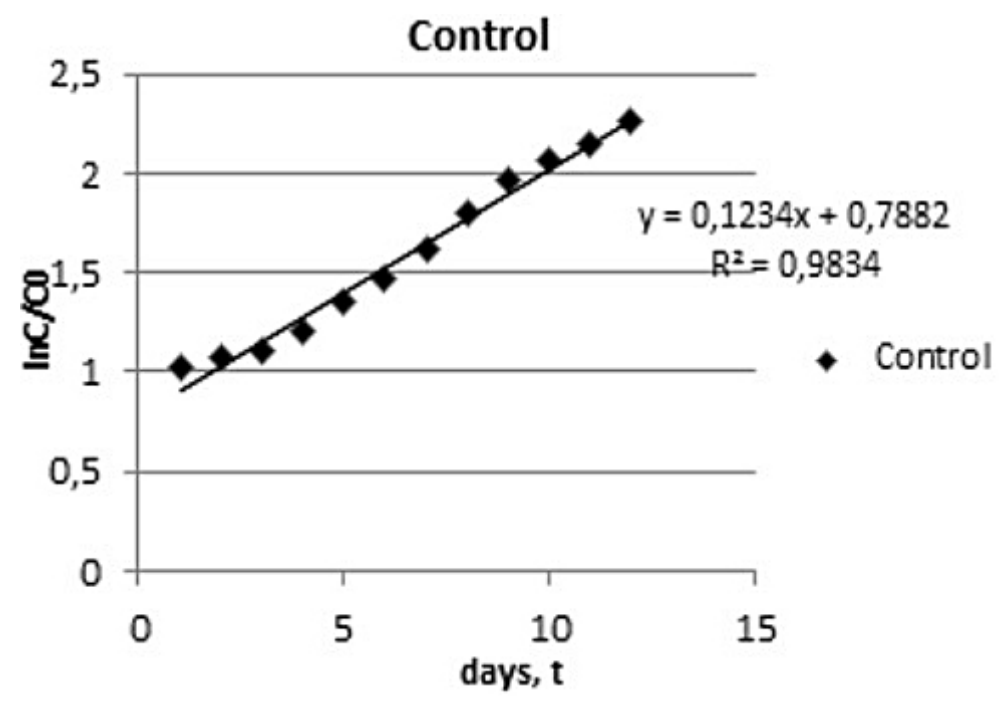

Fig. 5. Dependence of a change of the logarithm of cells concentration in microalgae suspension on time (control)

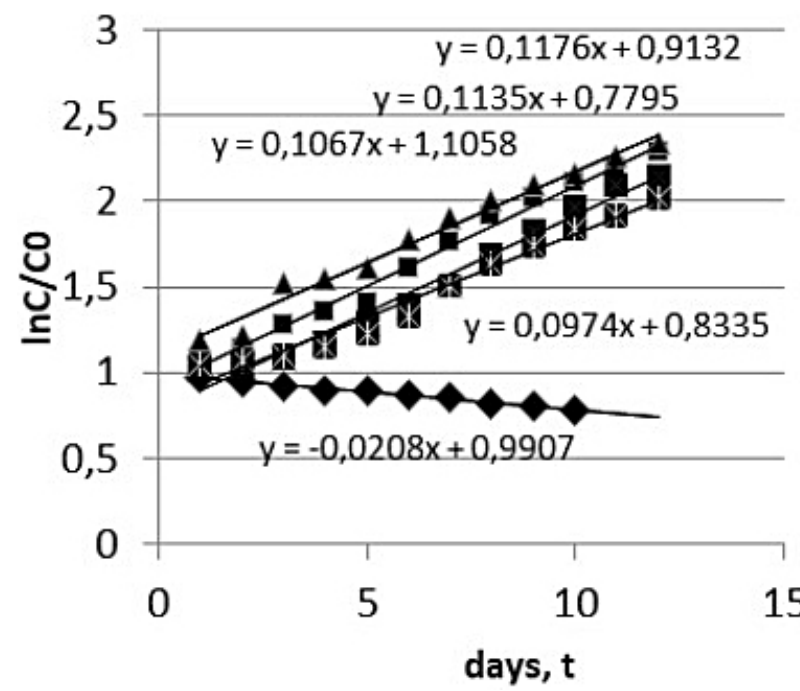

- №1

- №2

- №3

- №4

58 №5

Fig. 6. Dependence of a change of the logarithm of cells concentration in microalgae suspension on time (under the corresponding values of concentrations of the $\mathrm{NO}_{3}^{-}$activator and the $\mathrm{HSO}_{3}^{-}$permanent inhibitor) 
microalgae biomass growth is observed, and the corresponding value of the factor $\mu$ is negative.

The mathematical model, which describes the dynamics of growth of microalgae and thus, the dynamics of the carbon dioxide $\mathrm{CO}_{2}$ absorption looks like:

$$
\left\{\begin{array}{l}
\frac{d C}{d x}=\mu_{1} C-\mu_{2} C \\
\frac{d C}{d \mathrm{x}}=\mu_{1} C ; \\
x=0, C=C_{o} ;
\end{array}\right.
$$

where: $x-$ is concentration of activators $\left.\left(\mathrm{H}_{2} \mathrm{PO}_{4}^{-}\right) ; \mathrm{NO}_{3}^{-}\right)$in the presence of the inhibitor $\left(\mathrm{HSO}_{3}^{-}\right)$;

$\mathrm{C}$ - is concentration of microalgae in the suspension.

The solution of the presented model has some analytical expressions. One of them helps in calculating the optimal concentration of the activator in the presence of the inhibitor under its permanent concentration and known values of the growth factors $\mu$;

$$
x_{\max }=\frac{\ln \mu_{2}-\ln \mu_{1}}{\left(\mu_{1}+\mu_{2}\right)}
$$

Using the data of mathematical processing of the experimental research results on the microalgae growth, the authors found the coefficients $\mu_{l}$ and $\mu_{2}$. After inserting the obtained values into the solution of the mathematical model of the equation (1.14), it is possible to calculate an optimal value of the concentration of the phosphorus oxide $\mathrm{H}_{2} \mathrm{PO}_{4}^{-}$activator in the presence of the sulfur oxide $\mathrm{HSO}_{3}^{-}$inhibitor, under which the process of carbon dioxide absorption is the most efficient.

$$
\begin{gathered}
x_{\max }=\frac{\ln \mu_{2}-\ln \mu_{1}}{\left(\mu_{1}+\mu_{2}\right)}= \\
\frac{\ln (-0,0221)-\ln 0,0962}{(0,0962-0,0221)}= \\
=0,0067 \frac{\mathrm{Mr}}{\mathrm{M} 3} ;
\end{gathered}
$$

The solution of the mathematic model confirms that the maximum growth of the microalgae concentration is achieved under the concentration of the $\mathrm{H}_{2} \mathrm{PO}_{4}^{-}$anion $\approx 0.0067 \mathrm{mg} / \mathrm{m}^{3}$ in the presence of the $\mathrm{HSO}_{3}^{-}$anion.

Similarly, it is possible to calculate the optimal concentration of the $\mathrm{NO}_{3}^{-}$anion in the presence of $\mathrm{HSO}_{3}^{-}$, under which the process of carbon dioxide absorption is the most efficient.

$$
\begin{gathered}
x_{\max }=\frac{\ln \mu_{2}-\ln \mu_{1}}{\left(\mu_{1}+\mu_{2}\right)}= \\
=\frac{\ln (-0,0208)-\ln 0,1088}{(0,1088-0,0208)}= \\
=18,795 \frac{\mathrm{MI}}{\mathrm{N} 3} ;
\end{gathered}
$$

The solution of the equation (8) of the mathematical model argues that the dynamics of carbon dioxide absorption achieves its maximum under concentration of the $\mathrm{NO}_{3}^{-}$activator $\approx$ $18.795 \mathrm{mg} / \mathrm{m}^{3}$ and the permanent value of concentration of $\mathrm{HSO}_{3}^{-}=1000 \mathrm{mg} / \mathrm{m}^{3}$.

It means that the mathematical model provides a rather precise description of the studied process, and its solution secures forecasting of the main parameters of the technology of the greenhouse gases absorption in the presence of the inhibitor, i.e. sulfur oxide $\mathrm{SO}_{2}$ and activators, i.e. phosphorus oxide $\mathrm{P}_{2} \mathrm{O}_{5}$ and nitrogen oxides $\mathrm{N}_{x} \mathrm{O}_{y}$.

Table 2. Values of the growth factor $\mu$ under the corresponding concentrations of the $\mathrm{NO}_{3}^{-}$and $\mathrm{HSO}_{3}^{-}$anions

\begin{tabular}{|c|c|c|c|}
\hline Sample & Growth factor $\mu \mathrm{c}^{-1}$ & $\begin{array}{c}\text { Concentration } \mathrm{HSO}_{z}^{-} \mathrm{HSO}_{z}^{-} \\
\mathrm{mg} / \mathrm{m}^{3}\end{array}$ & Concentration $\mathrm{NO}_{z}^{-} \mathrm{NO}_{z}^{-} \mathrm{mg} / \mathrm{m}^{3}$ \\
\hline Control & 0.1234 & 1000 & - \\
\hline Sample No. 1 & -0.0208 & 1000 & 8.6 \\
\hline Sample No. 2 & 0.1176 & 1000 & 17.2 \\
\hline Sample No. 3 & 0.1067 & 1000 & 25.8 \\
\hline Sample No. 4 & 0.1135 & 1000 & 34.4 \\
\hline Sample No. 5 & 0.0974 & & 3 \\
\hline
\end{tabular}




\section{CONCLUSIONS}

1. The work demonstrated the phenomenon of inactivation of the sulfur oxide $\mathrm{SO}_{2}$ inhibitor by the phosphorus oxide $\mathrm{P}_{2} \mathrm{O}_{5}$ and nitrogen oxides $\mathrm{N}_{\mathrm{x}} \mathrm{O}_{\mathrm{y}}$ activators in the process of carbon dioxide absorption by the chlorophyll-synthesizing Chlorella microalgae.

2. The article presented the results of the experimental research on the efficiency of the carbon dioxide absorption by microalgae, depending on the concentration of activators under permanent concentration of the inhibitor.

3. The experiment showed an optimal correlation of the concentrations of sulfur oxide and phosphorus oxide, as well as sulfur oxide and nitrogen oxides, which secure the maximum intensive absorption of carbon dioxide by the chlorophyll-synthesizing microalgae.

4. The research determined the calculated value of an optimal correlation of the $\mathrm{H}_{2} \mathrm{PO}_{4}^{-}$and $\mathrm{HSO}_{3}^{-} ; \mathrm{NO}_{3}^{-}$and $\mathrm{HSO}_{3}^{-}$concentrations on the dynamics of the $\mathrm{CO}_{2}$ absorption by the chlorophyll-synthesizing microalgae.

\section{REFERENCES}

1. Climate change. National Ecological Center of Ukraine. (Available at: necu.org.ua/climate/)

2. Paris Agreement 2015. [Available at: https:// uk.wikipedia.org/wiki/]

3. Paris Climate Agreement: what happens and what are the results? (Available at: https://24tv.ua/parizka_klimatichna_ugoda_shho_vidbuvayetsya_i yaki_rezultati_n931921)

4. Economic forum in Davos 2020: about risks and lessons for Ukraine. (Available at: https://glavcom. ua/columns/b_danilishyn/ekonomichniy-forum-vdavosi-2020-roku-pro-riziki-ta-uroki-dlya-ukrajini-656005.html)

5. Zolotariova O.K., Shniukova Ye.I., Syvash O.O., Mykhailenko N.F. 2008. Prospects of microalgae use in biotechnology. Edit. by O.K. Zolotariova. K.: Alterpres, pp. 234.

6. Diachok V.V., Huhlych S.I., Katysheva V.V., Mandryk S.T. 2017. Absorption of carbon dioxide of the mixture of air and Sulphur dioxide. Scientific works, 81(1), 59-65.

7. Diachok V.V., S.T. Mandryk, V.V. Katysheva, S.I. 2018. Huhlych Investigation of the impact of nitrogen oxides on the speed of carbon dioxide absorption by chlorophyll-synthesizing microalgae in water environment. Journal of Lviv Polytechnic National University. Series: Chemistry, technology of substances and their application, 886, 171-176.

8. Diachok V., Mandryk S., Huhlych S. 2019. Activator of carbon dioxide absorption by chlorophyllsynthesizing microalgae. Environmental Problems, 4(2), 63-67.

9. Poltorak O.M., Chukhrai O.S. 1972. Physical-chemical fundamentals of fermentative catalysis. Edit. by M.M. Poplavska. M.: Vysshaia shkola, pp. 311.

10. Manakov M.N., Pobedimskii D.H. 1990. Theoretical fundamentals of the technology of microbiological production. M.: Ahropromizdat, pp. 272.

11. Diachok V., Mandryk S., Katysheva V., Huhlych S. 2019. Effect of Fuel Combustion Products on Carbon Dioxide Uptake Dynamics of Chlorophyll Synthesizing Microalgae. Journal of Ecological Engineering, 20(6), 18-26. 